\title{
Submarine landslides on the slope of a sandy barrier: a case study of the tip of the Hel Peninsula in the Southern Baltic
}

\author{
Stanisław RUDOWSKI ${ }^{1, *}$, Maria RUCIŃSKA-ZJADACZ ${ }^{2}$, Radosław WRÓBLEWSKI ${ }^{1,3}$ \\ and Patryk SITKIEWICZ ${ }^{3}$ \\ 1 Maritime Institute in Gdańsk, Department of Operational Oceanography, Długi Targ 41/42, 80-830 Gdańsk, Poland
2 University of Gdańsk, Department of Marine Geology, Al. M. Piłsudskiego 46, 81-378 Gdynia, Poland
3 University of Gdańsk, Department of Geomorphology and Quaternary Geology, Ba yńskiego 4, 80-952 Gdańsk, Poland
}

Rudowski, S., Rucińska-Zjadacz, M., Wróblewski, R., Sitkiewicz, P., 2016. Submarine landslides on the slope of a sandy barrier: a case study of the tip of the Hel Peninsula in the Southern Baltic. Geological Quarterly, 60 (2): 407-416, doi: 10.7306/gq.1291

The aim of the study is to present the occurrence of landslides on the submarine slope of a sandy barrier. The scale and significance of this phenomenon is discussed. The study area is the Hel Peninsula. It is a $35 \mathrm{~km}$ long young sandy spit. The landform is prograding into the deep part of Gdańsk Bay, and the underwater extension of its tip is a steep sandy slope. The tip is still poorly investigated, as it was a military area closed to researchers until 2003 . The first detailed survey of the tip on the seabed was conducted aboard the research vessel "IMOR". A multibeam echosounder, a sub-bottom profiler and a side-scan sonar were used, while grab and core samples of sediment were obtained. Many forms, commonly created as the result of underwater mass movement, were recognized and determined (main scarps, main bodies, landslide steps, landslide foots, series of small slides, "sheet" slides and structural slides). On the one hand, the landslide processes that occur in the tip of the Hel Peninsula are related to the natural development of sandy spits. On the other hand, they threaten the shore's stability. The genesis of the landslides is still not known.

Key words: underwater mass movements, sandspit, digital terrain model, side-scan sonar, sub-bottom profiling.

\section{INTRODUCTION}

The aim of the study is to present the occurrence of landslides on the submarine slope of a sandy barrier, and to reveal the general scale of this phenomenon and its significance to evaluate the state and development of the Hel Peninsula and other subaqueous slopes of sandy barriers, deltas and excavation walls. The study is based on materials from pioneering research conducted at the tip of the Hel Peninsula in 2006-2007 (Rucińska-Zjadacz, 2013).

The study area is the tip of the Hel Peninsula (Fig. 1). The Hel Peninsula is the most characteristic feature of the Polish coastline. It is a $35 \mathrm{~km}$ long sandy spit, $150 \mathrm{~m}$ wide at its base and $3 \mathrm{~km}$ wide at its head.

The hydrometeorological conditions of the tip are specific and complex (Rucińska-Zjadacz and Rudowski, 2009, 2015). It is exposed to winds and waves from every direction, though the westerly winds are dominant (Miętus and Jakusik, 2005). The large depth (over $60 \mathrm{~m}$ ) around the tip makes the waves from

\footnotetext{
* Corresponding author, e-mail: starud@im.gda.pl
}

Received: July 22, 2015; accepted February 17, 2016; first published online: April 12, 2016 the open sea come directly to the shore with very strong and direct effect. The crests of the waves are subjected to strong and varied refraction causing multi-faceted interference systems. This is important for the formation of a complex and distinct system of surface and shelf/slope currents, including upwelling and downwelling. So far, no adequate specialized hydrodynamic research has been conducted in the area of the tip. Existing information about hydrodynamic conditions of this region come from the studies dealing with the Hel Peninsula (e.g., Miętus et al., 2005; Stanisławczyk, 2005) or the Polish coast as a whole (Pilarski et al., 2011).

The development of the Hel Peninsula, like the whole Southern Baltic coast, is mainly related to the period of the Littorina Transgression and the last relative stabilization of the sea level (Uścinowicz, 2014). During the transgression period, the coast of moraine plateau was abraded and its sediment was transported longshore in an eastern direction. The Hel Peninsula was formed as a spit following the deposition of this sediment (Tomczak, 1995a). The embryonic spit developed towards the centre of Gdańsk Bay. The northern shore of the spit was purely an extension of the land shoreline. Due to a later sea-level rise, the Southern Baltic seashore was retracted. The spit moved on towards the south, until it reached land sediment. About 5500 years ago, the sea level became relatively stabilized. The Hel Peninsula had been growing very fast, until it reached a deep part of the Gulf of Gdańsk. After that, the devel- 


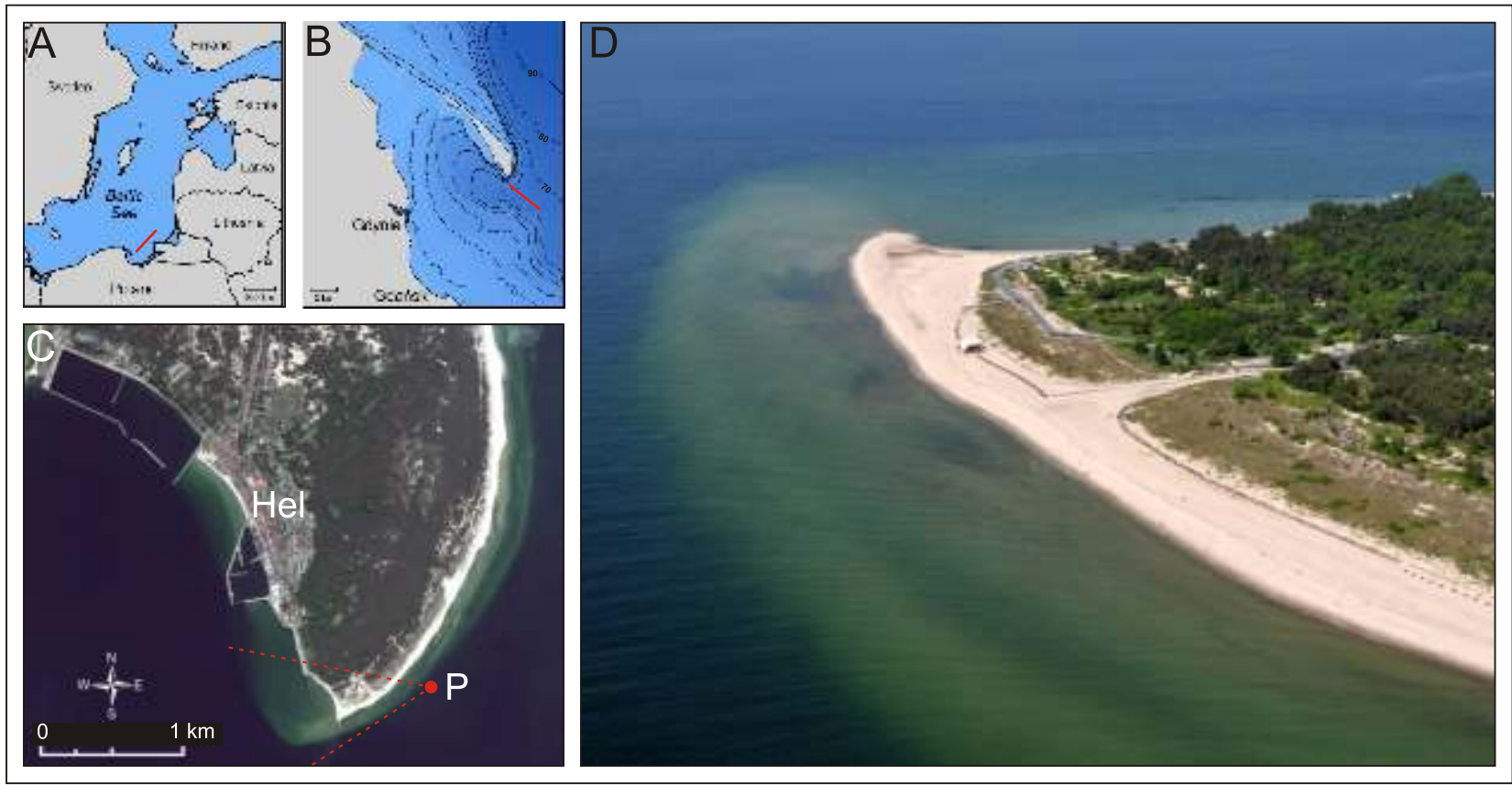

Fig. 1. Location of the study area

A - situation on the Baltic Sea; B - situation on the Gulf of Gdańsk; C - satellite image (DigitalGlobe after Google Ink., 2015, taken on 1 June, 2014); D - aerial photo of the tip of Hel Peninsula (taken by P. Domaradzki on 7 June, 2013);

$\mathrm{P}$ - viewpoint of the aerial photo (D) marked on the satellite image (C)

opment of the spit became slower (Tomczak, 1995a; Uścinowicz, 2003). About 1760 years ago the tip of the Hel Peninsula reached the place where the town of Hel is located today, and about 1000 years ago the shape of the spit became similar to the present shape of the Hel Peninsula (Tomczak, 2005).

A $100 \mathrm{~m}$ thick layer of Holocene sediment, found in most phases of the Baltic development, is located on the distal part of the Hel Peninsula (Tomczak, 1995b). Lithology and biostratigraphy of individual parts of the layer have been generally determined based on drilling results. These are sandy and muddy deposits from subsequent phases of the Baltic Sea development (Tomczak, 2005). These layers lie consecutively on Pleistocene tills (ca. $10 \mathrm{~m}$ thick) and Cretaceous marly rocks (whose top is at about $100 \mathrm{~m}$ b.s.l.) (Tomczak, 1995b).

The underwater slope of the Hel Peninsula tip is composed of a series of colluvium deposits, primarily medium- and fine-grained sand. Pebbles, fragments of peat, organic detritus and other elements also occur there (e.g., Musielak, 1989; Kramarska, 1995; Tomczak, 2005). The sea-floor around the tip is composed of fine-grained silty sand and sand-silt-clay sediment (Kramarska, 1995). The underwater part of the tip of the Hel Peninsula is a steep slope (locally $20^{\circ}$ or more). The foot of the slope is located at a depth of nearly $60 \mathrm{~m}$ (Rucińska-Zjadacz and Rudowski, 2009). As regards non-tidal basins, there are few formations of this type in the world. The most similar landform is Long Point on Lake Erie, but its slope is not so steep and its foot is located at merely $40 \mathrm{~m}$ b.s.l. (Davidson-Arnott and Conliffe Reid, 1994).

Only a few studies have been conducted in the region of the tip of the Hel Peninsula, and all of them on the shore (Wünsche, 1904; Łęgowski, 1925; Bączyk, 1963; Grygorenko, 1972; Graniczny et al., 2004). Results of these studies show that the tip is growing towards the south-east; however, the western shore is eroded. There are some reasons for the lack of studies in this region. First, the area was closed for researchers until 2003 , because it had been a military area. Secondly, precise methods of recognizing seabed features have not been affordable in the past.

Submarine mass movement is hard to be observed in action. Usually, only effects of the process are recordable (landforms and deposits). In our times, non-invasive methods (mainly: a multibeam echosounder, a sub-bottom profiler and a sidescan sonar) can be used to survey a submarine landslide. These methods are a good tool for obtaining the characteristics of the slide (Canals et al., 2004; Gazioğlu et al., 2005; Sichi et al., 2005; Bozzano et al., 2009). The results obtained based on a classic analysis of sediments were of limited significance because grab samples are collected from random points without the relation to the forms of sea-floor relief. The main basis for determining the slope relief and nature of its surface is full spatial (no interpolation between measurement points) registration of the sea-floor surface and seismic profiling. The results of particle-size distributions and the descriptions of core samples could only be used aiding with the geological interpretation of geophysical data.

The first studies concerning the underwater tip of the Hel Peninsula were conducted in the years 2006-2007 (Rucińska-Zjadacz and Rudowski, 2008, 2009, 2015; Rucińska-Zjadacz, $2013,2015)$. A similar work was performed in the nearby area of the Hel Port (Rudowski et al., 2015).

\section{METHODS}

The research area is a ca. $1 \mathrm{~km}$ wide polygon surrounding the tip and parallel to the shoreline. It includes the underwater slope of the tip of the Hel Peninsula (Fig. 2). The study is based on materials from the pioneering research carried out in 2006 and 2007 (Rucińska-Zjadacz, 2013). Surveys were conducted aboard the research vessel "IMOR" by the staff of the Department of Operational Oceanography of the Maritime Institute in Gdańsk. 


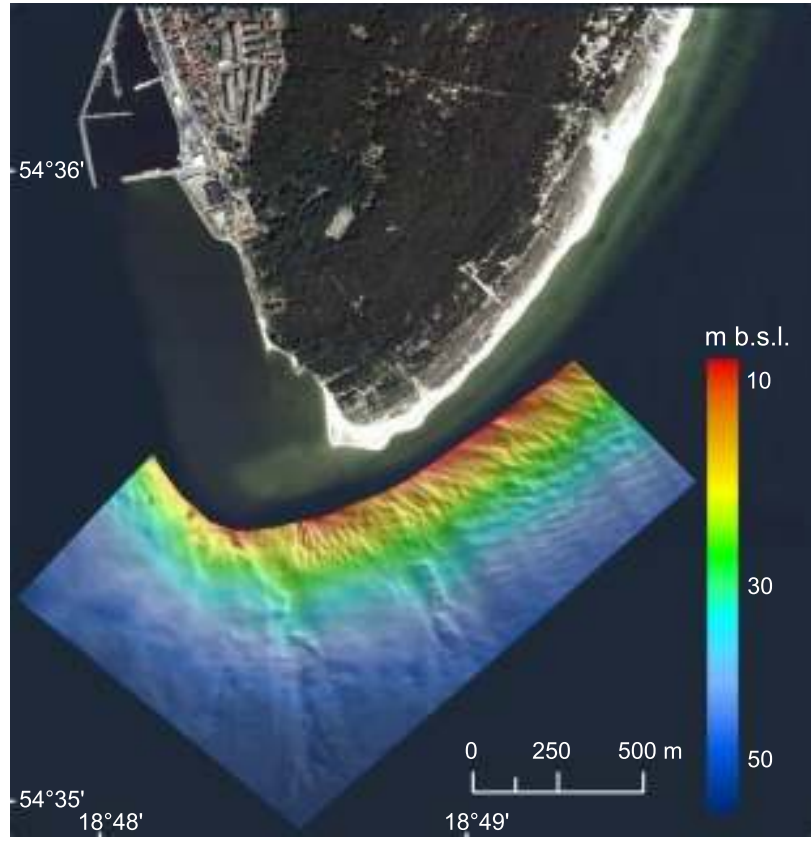

Fig. 2. Relief image of the study area (Rucińska-Zjadacz and Rudowski, 2009)

The picture of the land is the orthophotomap (CODGiK, July 10, 2010)

A relief survey was performed using a multibeam echosounder (Seabat 8101). Based on the obtained point cloud, a digital model of the bottom was generated, and a full spatial image of the sea-floor relief was achieved.

The character of the seabed surface was recorded by a sidescan sonar (EdgeTech MF4200) and, locally, by an underwater TV (ROV TV system).

Twelve seismic profiles (Fig. 3) were performed by sub-bottom profilers SeaBat Oretech 3010 and AG\&G Boomer, to find out the inner structure of the slope. The archived resolution of the seismic record is ca. $0.3 \mathrm{~m}$ with $2-3 \mathrm{~m}$ of penetration. The deeper parts of the seismic profiles are not useful for interpretation because there are numerous crossed lateral and vertical multiple reflections, related to the sea-floor morphology and the configuration of landslide layers.

Additionally, three core samples (by a vibrocorer VKG-3) and 62 grab samples (by a Van Veen Grab Sampler) were collected (Fig. 3; Rucińska-Zjadacz, 2013). The macroscopic descriptions and sieve analysis (1 phi) were performed.

The results of the non-invasive recording methods were geologically interpreted based on knowledge of the region (e.g., Pikies and Jurowska, 1992; Uścinowicz and Zachowicz, 1992; Tomczak, 2005) and experience in the methods (Fish and Carr, 1990; Blondel and Murton, 1997; Stoker et al., 1997; Blondel, 1999; Lurton, 2002; Sichi et al., 2005; Grządziel, 2008; Rudowski and Rucińska-Zjadacz, 2010). Sonograms were determined from the sidescan sonar images. They identified areas that have a similar character to the bottom surface, with respect to the physical features of the sediment (grain-size, density and compaction) and the relief features of the sea-floor. Seismic facies were distinguished on the sub-bottom profiler records by considering the character of the reflections. The lithology of the sediment is connected with the scattering and absorption of acoustic energy (Badley, 1985; Stoker et al., 1997; Wicher and Necel, 2000; Przezdziecki, 2004; Rudowski and Rucińska-Zjadacz, 2010). Geological interpretation of the seismoacoustic records was performed with consideration of the core and grab samples.

\section{RESULTS}

The analysis of 62 grab samples reveals a significant variability in surface sediments of the submarine slope. Based on the obtained results, the features of sediments have been described related to the main morphological forms (macroforms) (Figs. 4 and 5), including a coastal shallow, slope edges, slope surface, and slope foreland. The results are concerned the eastern, the central and the west profiles (Fig. 4).

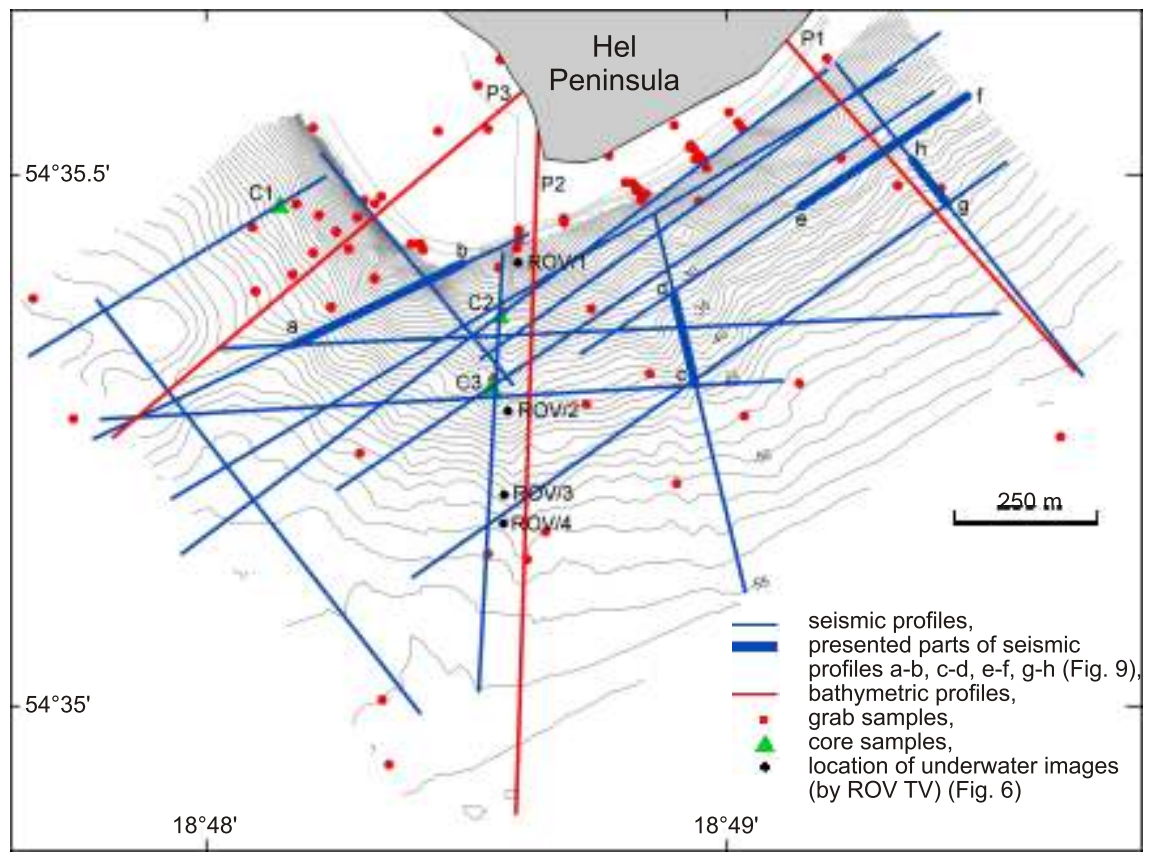

Fig. 3. Documentation map 
The differentiation of surface sediments is highlighted by the chaotic presence of various elements deposited on the slope and foreground (Fig. 6) due to abrasion of the Hel Peninsula shores. These are fragments of trunks and branches, plant detritus, concrete rubble, gravel and stones, fragments of animal bones (mainly fish) etc. The diverse nature of the sediments is also been observed in the sediment boreholes (Fig. 7). There are interlayers of relatively well-sorted fine sand and silty sand as well as unsorted sand. Consequently, the nature of the sediments is compatible with the classical colluvium concept, including downslope transport and slides of the material from abundant supply of full-term diversified sediments on the slope and foreground.

An accurate overall picture of the seabed surface has been archived using non-invasive methods in order to recognize the sea-floor relief. Numerous, common submarine mass movements, varied in size and type, have been observed. Selected examples are presented and described below.

Large fully developed landslides occurred in the central part of the tip. Their main scarps and main bodies were recognized
(Fig. 8). The main bodies were composed of fine sand and silty sand, with the addition of coarse sand and clay. The sediment was poorly sorted. More fine-grained sediment is observed on the underside of the main bodies than on the upper sides. A number of bricks, and pieces of concrete and wood were also found on the surfaces of the main bodies. These included fragments of destroyed defence coastal forms and buildings, as well as anthropogenic rubbish.

Three main seismoacoustic facies were distinguished within the inner structure of the slope. These are: facies I - recent surface sediment, facies II - young colluvium, and facies III - older colluvium. The examples of the seismic records are presented in Figure 9.

Facies I - recent surface sediment. It is a thin cover lying on a relatively flat slope area. Its thickness is roughly from 20 to $50 \mathrm{~cm}$. It arose from the gravitational accumulation of suspension, and is composed of fine sand in the shallower parts of the tip and fine silty sand in its deeper parts.

Facies II-young colluvium. The seismoacoustic image of the top boundary of the facies owes its features to the occur-
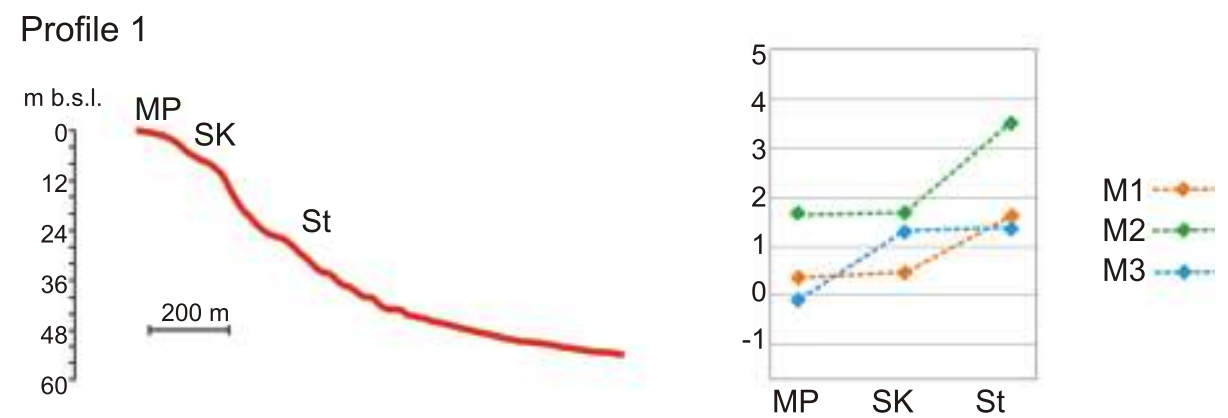

Profile 2
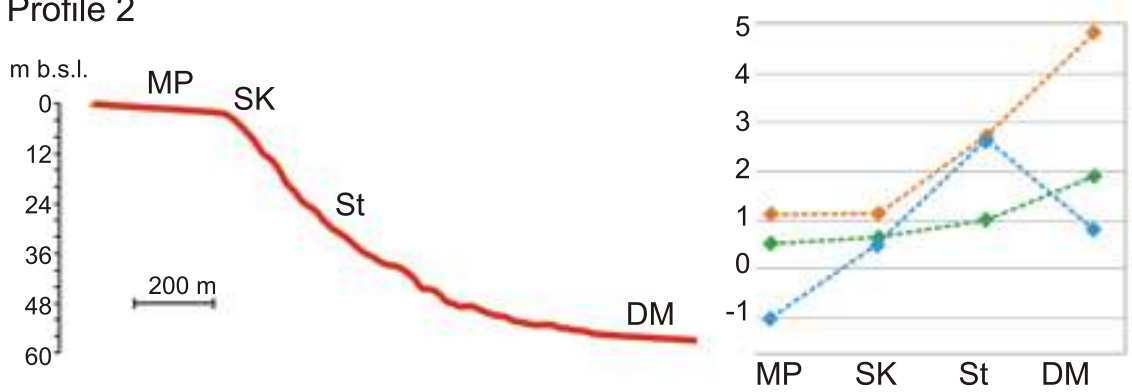

Profile 3
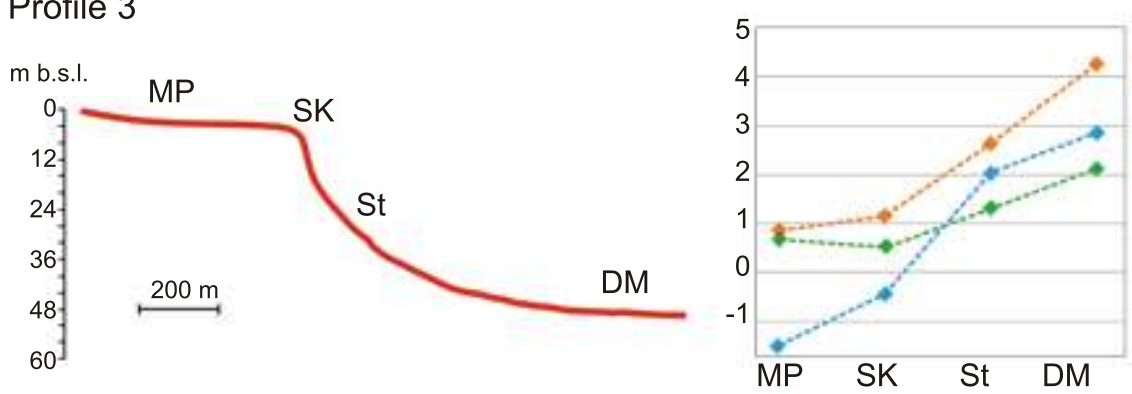

Fig. 4. Differentiation of grain-size parameters (in phi units) of surface sediments within bathymetric profiles: 1, 2 and 3 (profile locations on Fig. 3)

MP - coastal shallow sediments, SK - edge zone sediments, St - slope sediments, DM - slope base sediments, M1 - mean, M2 - standard deviation, M3 - skewness 


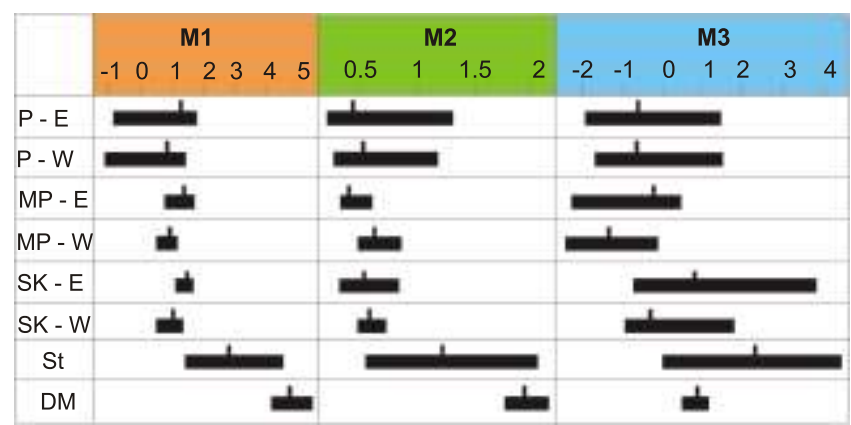

Fig. 5. Grain-size parameter values of surface sediments within the morphological units (vertical markers indicate average values)

Units: P - beach, MP - coastal shallow, SK - edge zone; E - eastern part of cape, W - western part of cape, St - slope, DM - slope base; M1 - mean, M2 - standard deviation, M3 - skewness (after Rucińska-Zjadacz and Rudowski, 2015)

rence of shells and pebbles that are commonly found in vibrocore samples. The lower boundary of the facies is ragged and erosive. The thickness of the facies ranges from a few decimetres on the upside of the slope to $6 \mathrm{~m}$ on the underside. The facies is interpreted as belonging to a group of young landslide formations with characteristic disturbed sandy sediment.

Facies III - older colluvium. The recorded image is similar to the Young Colluvium Facies, but the reflections are stronger.
The thickness of the facies is $>10 \mathrm{~m}$. The layer below the boundary is not visible in the detail on the records. The landslide material is composed of highly compacted variously grained sand, including toppled rubble.

A relatively vast, flat, shallow bottom is located near the steep slope of the tip. It is an area under action of waves and currents only, without landslides.

Two main very steep (up to $35^{\circ}$ ) scarps are observed (Fig. 8), with edges located $7 \mathrm{~m}$ b.s.l. Interpretation of their inner structure (profile a-b in Fig. 9) confirms the correctness of the identification of the form.

Only the upside of the main body "A" (Fig. 8), genetically related to the main scarp no. 1 , has remained. The rest of the main body may have been distributed on the slope and/or the landslide that is genetically related to the main body "B". It may also be associated with the convex parts of the slope located 50-55 m b.s.l., which are interpreted as a landslide foot.

The main body " $\mathrm{C}$ " (Fig. 8) is composed, among others, of materials that have slid from the main scarp no. 2. This landslide is probably the youngest of all. It lies on the inside of a long narrow landslide furrow valley. The distal part of the main body is an elongated fan, and numerous steps are on the surface of the form.

The main scarp associated with the main body "D" (Fig. 8) has not survived. It was buried by material transported across the slope from the north-east to the south-west. The surface of the main body " $\mathrm{D}$ " is thinly ridged. It is located inside a wide landslide furrow valley, and is split by an inlier trough. There are many steps on the inlier trough, which may be older than

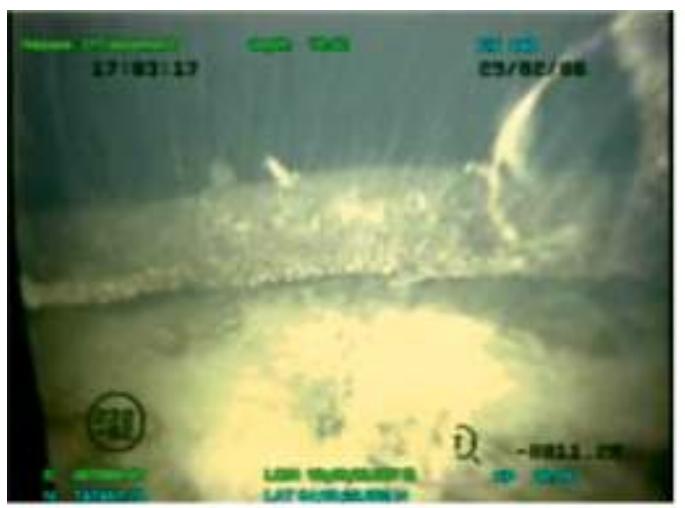

$\mathrm{ROV} / 1$

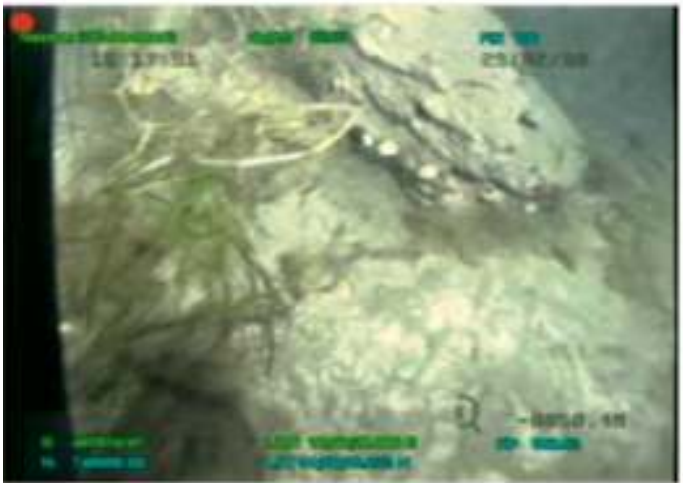

$\mathrm{ROV} / 3$

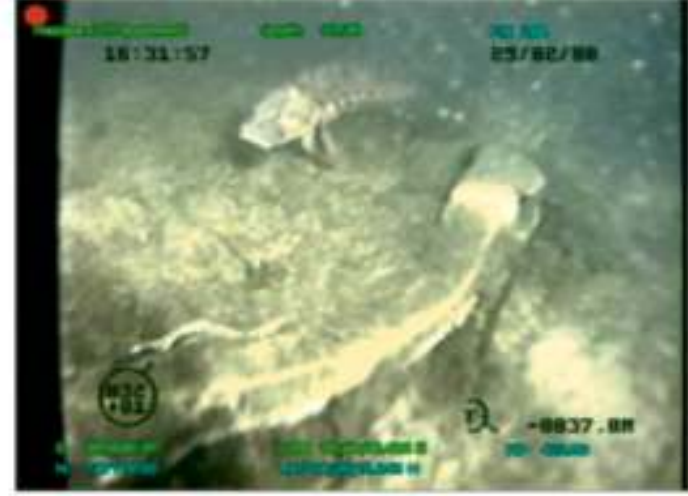

$\mathrm{ROV} / 2$

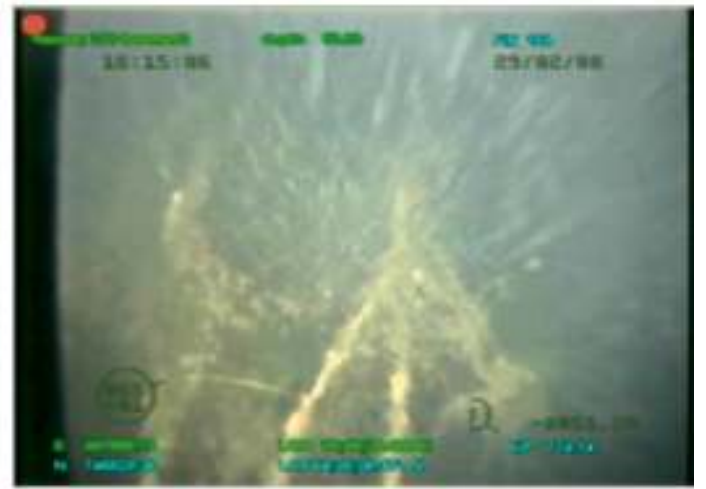

$\mathrm{ROV} / 4$

Fig. 6. Examples of underwater photos (ROV TV of the different objects on the slope (part of a tree trunk and limbs, concrete and various rubbish) 


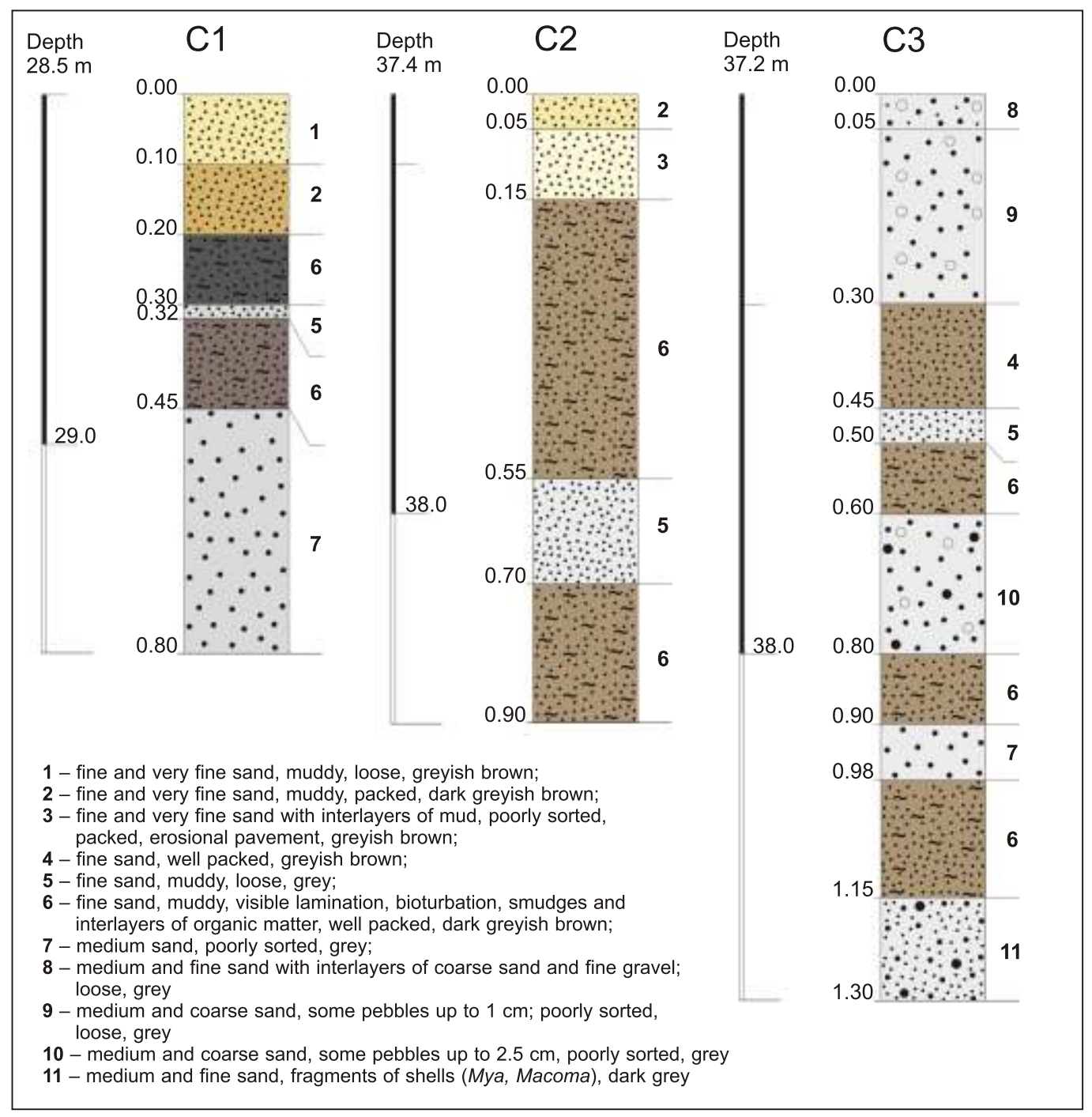

Fig. 7. Borehole sections

For location see Figure 3

the surrounding dichotomous main body, or may have arisen as a result of sliding in the main body sediment. The distal part of the main body is composed of a series of wide foot fans (Figs. 2 and 8).

The eastern part of the tip (Fig. 8) is composed mainly of medium-grained and fine-grained sand. The rate of longshore sediment transport from the north is high, while the cross-shore transport is diverse. Three types of slide (Fig. 10) can be determined by considering their size and character. These include: a series of small slides, "sheet" slides (the forms of flat surface, which are displaced) and structural slides (the forms that are displaced in conformity with the bedding plane and the structure, but not with the truncation of crosswise structures). These have been classified by analogy to landslides that occur on land (vide Kleczkowski, 1955; Klimaszewski, 1978; Hampton et al., 1996; Einsele, 2000; Migoń, 2015).

Numerous steps are found in the underside of the slope (profile $\mathrm{g}-\mathrm{h}$ in Fig. 9). These are relatively firm, and their clear relief is an indication of a low rate of sediment deposition. Between the steps the depth differences are about $2 \mathrm{~m}$. The formations are composed mainly of fine sand.
A single step is observed in many places on the tip. These have arisen as a result of mass movement, like a translational landslide, in conditions of ample sediment accumulation. They are composed mainly of fine sand, but also contain coarse materials, including fragments of bricks, concrete elements, roots and branches of trees.

\section{DISCUSSION}

The presented submarine landslides occur on the steep sandy slope of a barrier moving on a deep non-tidal basin. So far, landslides of different scales and lithologies have been described occurring on continental slopes (e.g., Hampton et al., 1996; Mulder and Cochonat, 1996; Adams et al., 1998; McAdoo et al., 2000; Beyer et al., 2003; Canals et al., 2004; Hühnerbach and Masson, 2004; Gazioğlu et al., 2005; Masson et al., 2006; Elverhoi et al., 2010), large river deltas (e.g., Prior and Suhayda, 1979; Nemec, 1990), and underwater slopes of lakes (e.g., Gardner et al., 2000; Bozzano et al., 2009). Subaqueous landslides have been observed in Poland on the bot- 

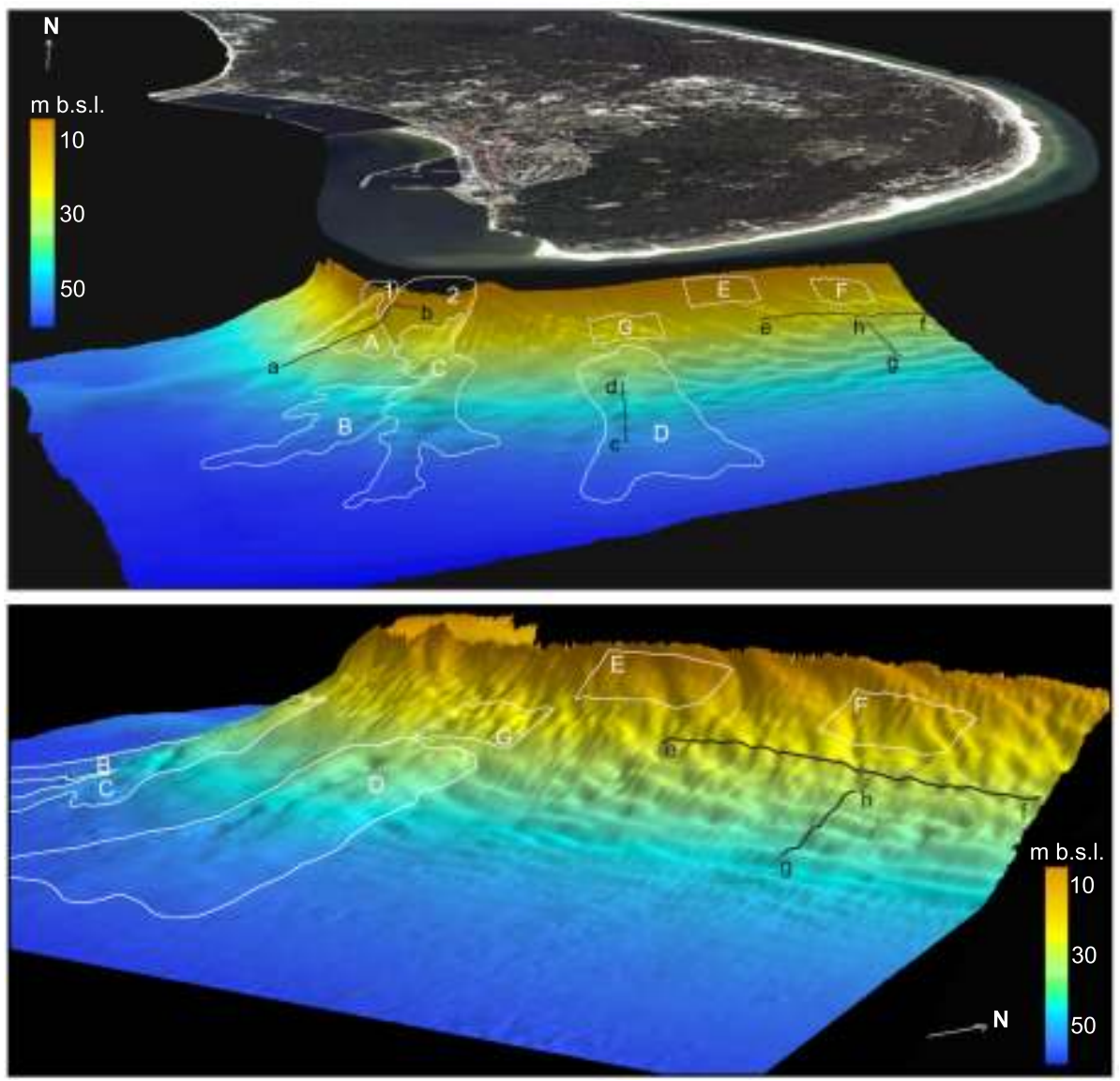

Fig. 8. Relief image of the Hel Peninsula tip

The south-perspective is on the top and the east-perspective is beneath; landslide's main scarps $(1,2)$ and the main bodies $(A-D)$ are marked by white lines; seismic profiles $a-b, c-d, e-f, g-h$ (Fig. 9) are marked by black lines; examples of sonar images (Fig. 10) are contoured by white lines; the picture of the land is the orthophotomap (CODGiK, July 10, 2010)

tom of Wigry Lake (Rutkowski et al., 2003) and at the excavation walls created as a result of sand exploration in the Puck Lagoon (Rudowski et al., 2009). Landslide processes may also occur near the tip of the Hel Peninsula - at the unexplored western slope of the Hel Peninsula in the region of the Długa Shoal and the Bórzyńska Shoal. However, this question requires further investigation.

The classification of landslide forms and phenomena, especially subaqueous, requires evolving. In this paper, the slides, "sheet" slides and structural slides have been classified by analogy to landslides that occur on land. Presented results may be a starting point to a discussion on types and nature of landslide forms on submarine slopes of sandy barriers.

The multibeam echosounder survey was repeated after 17 months. During this period, neither relief nor landslide development was observed. No relief changes to the tip were noticed, either. They were not occasioned even after the intended detonation (in February, 2009) of a wreck from World War II (a barge with mines), lying in the western part of the slope (Rucińska-Zjadacz, 2013). Nevertheless, the clear relief and the inner structure of the slope indicate that changes occur occasionally and they may be significant.
The origin for the landslides has not been unequivocally determined. Many factors could cause instability of the slope of the Hel Peninsula tip, and there are many options to consider. Landslides occur primarily as a result of sediment overload (Løseth, 1999). Water mass movement (wind waves, sea level changes, internal waves) can also cause a slide (Hampton et al., 1996; Mulder and Cochonat, 1996; Løseth, 1999; Hühnerbach and Masson, 2004). One of the results of wave action is cyclical changes to the pore water pressure, which can cause sediment to loosen (Løseth, 1999). Sea level changes can also activate changes in groundwater pressure, and the result can be a slide. Wave-generated vibrations are also an important slide factor. Landslides at the tip of the Hel Peninsula can also occur as the result of exceptionally strong storm. Other probable reasons for landslides in the Hel Peninsula tip are earthquakes (such as the 2 tremors that occurred on 21 September 2004, 5.0 and 5.3 in magnitude, with their epicentre in the Kaliningrad Oblast; Wiejacz, 2006), and the loosening of sediment compaction due to the decay of organic matter. The presence of great gas eruptions (e.g., gas volcanoes with craters over 200 metres in diameter; Rudowski et al., 2010) on the seabed around the Hel Peninsula tip should 


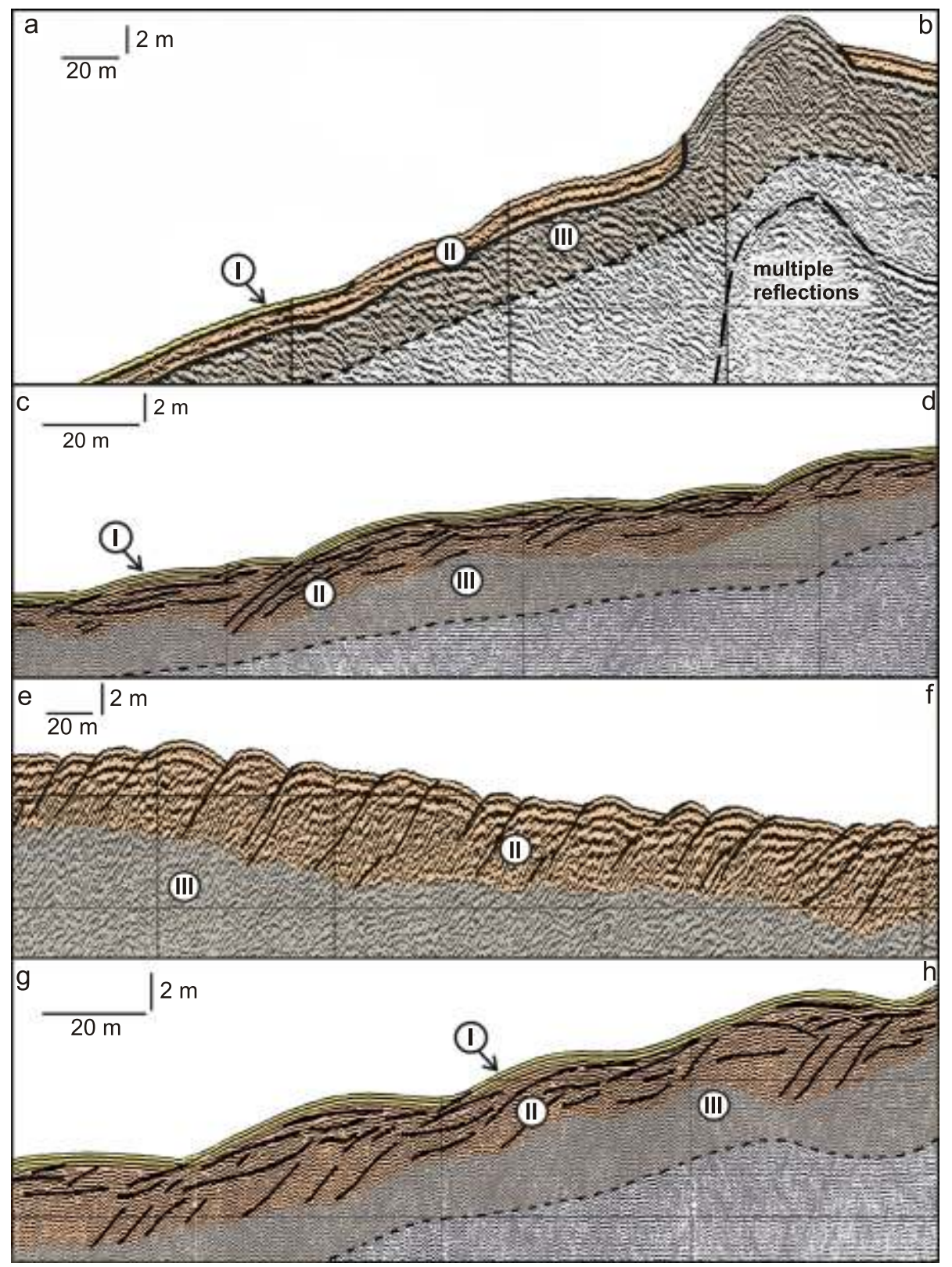

Fig. 9. Examples of seismic profiles: a-b, c-d, e-f, g-h (for location see Figs. 3 and 8)

Facies: I - recent surface sediment, II - young colluvium, III - older colluvium; interpretable area is coloured

also be considered as a potential capability to activate landslides on the slopes.

On the one hand, the landslide processes that occur on the tip of the Hel Peninsula are connected with the natural development of a sandy spit. But on the other hand, they threaten the shore's stability. This is especially risky in the western part of the tip, with a highly urbanized coast and eroded shore (Rucińska-Zjadacz, 2015; Rucińska-Zjadacz and Rudowski, 2015). So far, the impact of the processes that occur on the submarine slope has not been taken into account in any studies of the dynamic state of the Hel Peninsula, including those examining the sedimentary budget and the shore abrasion hazards.

The problem requires further research, especially given that the area has been poorly investigated from a hydrodynamic, geomorphologic and tectonic point of view. The submarine landslides are a challenge for engineering geology.

The morphology should be monitored, and the development of the slope should be observed. This is all the more significant because the condition and the development tendencies of the whole landform - the Hel Peninsula - are manifested via the condition of the tip. 

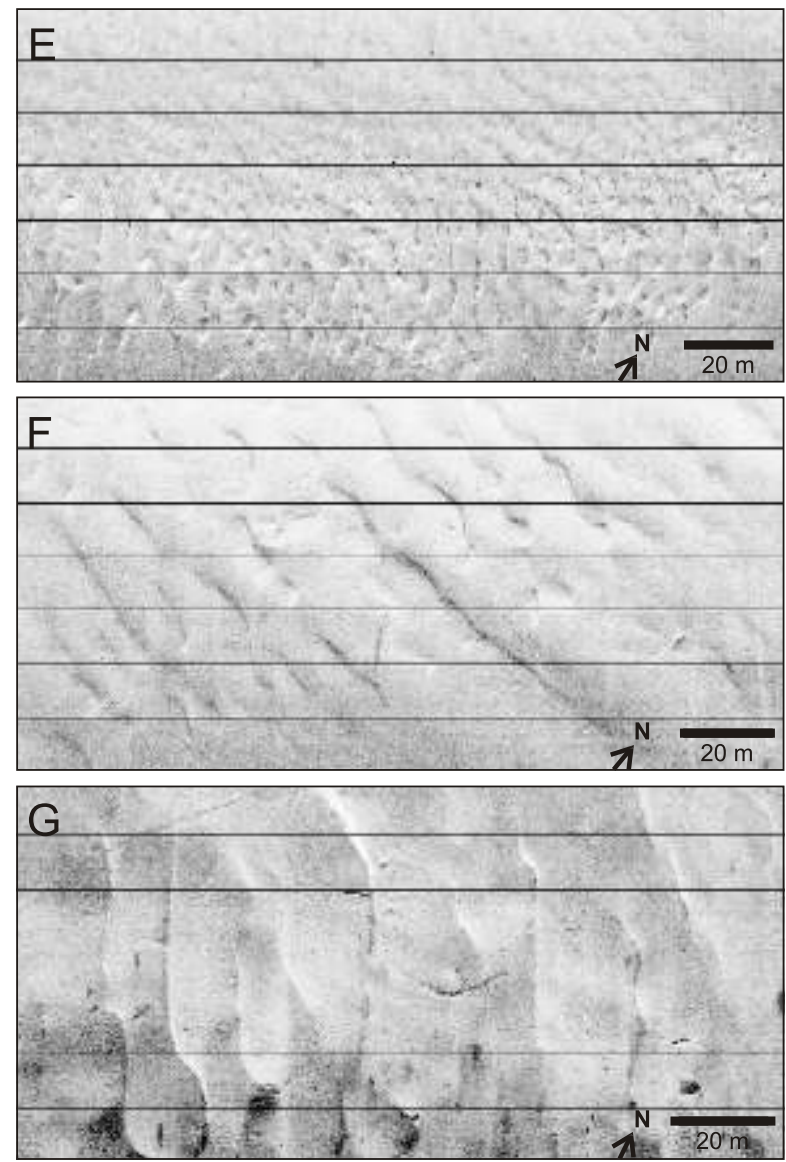

Fig. 10. Sonar images of three types of slide: $E$ - series of small slides, F - "sheet" slides, G - structural slides

\section{CONCLUSIONS}

This is the first detailed presentation of the relief of the submarine slope of a sandy barrier known to authors. The work is essential for any discussion on the structure development and state of underwater sandy slopes (e.g., barriers, deltas, excavation walls) for utility and cognitive purposes.

The commonly observed submarine mass movements, varied in size and type, have formed colluvial sediments, tens of metres in thickness.

The presented results show a clear dependence of the development of the submarine slope on the lateral supply of sediment from the shore. The western part of the slope surface, with lower sediment supply, is erosive causing abrasion of the shore. The eastern part is a clear accumulation area, and the central part of the tip is in a relative equilibrium state with a predominant deposition process.

The presented material shows a lack of terminology in distinguishing and classifying significant differences of underwater landslide forms, since the previous experience is related mainly to large forms on steep continental slopes in deep waters. The results can be a contribution to work in this field.

The presented material provides a good base to carry out further detailed monitoring and specialist studies (geomorphological, geological and hydrodynamic) that are necessary for the proper diagnosis of the causes and rate of change in the slope under the influence of certain factors and processes, e.g. the determination of geotechnical properties to monitor the changes, determining the action of wind waves in the basin, and occurrence of internal waves, currents, etc.

Acknowledgements. We would like to thank J. Nowak and all of the staff of the Department of Operational Oceanography of the Maritime Institute in Gdańsk for performing the surveys and preparing the dataset. Journal referees N. Blažauskas and A. Wysocka are also acknowledged for their comments.

\section{REFERENCES}

Adams, E.W., Schlager, W., Wattel, E., 1998. Submarine slopes with exponential curvature. Sedimentary Geology, 117: 135-141.

Bączyk, J., 1963. Genèse de la Presqu'île de Hel, sur la base du développement du Golf de Gdańsk (in Polish with French summary). Dokumentacja Geograficzna, 6, Instytut Geografii PAN, Warszawa.

Badley, M.E., 1985. Practical Seismic Interpretation. International Human Resources Development Corporation, Boston.

Beyer, A., Schenke, H.W., Klenke, M., Niederjasper, F., 2003. High resolution bathymetry of the eastern slope of Porcupine Seabight. Marine Geology, 198: 27-54.

Blondel, P., 1999. Textural analysis of sidescan sonar imagery and generic seafloor characterization. Journal of the Acoustical Society of America, 105: 1206.

Blondel, P., Murton, B.J., 1997. Handbook of Seafloor Sonar Imagery. John Wiley and Sons, Chichester.

Bozzano, F., Mazzanti, P., Azidei, M., Esposito, C., Floris, M., Fasani, G.B., Esposito, A., 2009. Slope dynamics of Lake Albano (Rome, Italy): insights from high resolution bathymetry. Earth Surface Processes and Landforms, 34: 1469-1486.

Canals, M., Lastras, G., Urgeles, R., Casamor, J.L., Mienert, J., Cattaneo, A., De Batist, M., Haflidason, H., Imbo, Y., Laberg, J.S., Locat, J., Long, D., Longva, O., Masson, D.G., Sultan, N., Trincardi, F., Bryn, P., 2004. Slope failure dynamics and im- pacts from seafloor and shallow sub-seafloor geophysical data: case studies from COSTA project. Marine Geology, 213: 9-72.

Davidson-Arnott, R.G.D., Conliffe Reid, H.E., 1994. Sedimentary processes and the evolution of the distal bayside of Long Point, Lake Erie. Canadian Journal of Earth Science, 31: 1461-1473.

Einsele, G., 2000. Sedimentary Basins. Evolution, Facies and Sediment Budget. Springer-Verlag, Berlin.

Elverhoi, A., Breien, H., De Blasio, F.V., Harbitz, C.B., Pagliardi, M., 2010. Submarine landslides and the importance of the initial sediment composition for run-out length and final deposit. Ocean Dynamics, 60: 1027-1046.

Fish, J.P., Carr, H.A., 1990. Sound underwater images: a guide to the generation and interpretation of side scan sonar data. Lower Cape Pub., Orleans.

Gardner, J.V., Mayer, L.A., Clarke, J.E.H., 2000. Morphology and processes in Lake Tahoe (California-Nevada). GSA Bulletin, 112: 736-746.

Gazioğlu, C., Yücel, Z.Y., Doğan, E., 2005. Morphological features of major submarine landslides of Marmara Sea using multibeam data. Journal of Coastal Research, 21: 664-673.

Google Inc., 2015. Google Earth Pro 7.1. Computer software. Mountain View.

Graniczny, M., Janicki, T., Kowalski, Z., Uścinowicz, S., Zachowicz, J., 2004. Geoindicators of the coastal zone - regis- 
tration and analysis of processes and phenomena (in Polish with English summary). Przegląd Geologiczny, 52: 47-54.

Grygorenko, W., 1972. Ewolucja wierzchołka Półwyspu Helskiego (badania metodą kartograficzną) (in Polish). Przegląd Geodezyjny, 49: 417-418.

Grządziel, A., 2008. Technika sonaru bocznego w badaniach hydrograficznych (in Polish). Przegląd Hydrograficzny, 4: 79-85.

Hampton, M.A., Lee, H.J., Locat, J., 1996. Submarine landslides. Review of Geophysics, 34: 33-59.

Hühnerbach, V., Masson, D.G., 2004. Landslides in the North Atlantic and its adjacent seas: an analysis of their morphology, setting and behavior. Marine Geology, 213: 343-362.

Kleczkowski, A., 1955. Osuwiska i zjawiska pokrewne. Terminologia, charakterystyka zjawisk, przyczyny powstawania, metody badań, klasyfikacja, literatura (in Polish). Wyd. Geol., Warszawa.

Klimaszewski, M., 1978. Geomorfologia (in Polish). PWN, Warszawa.

Kramarska, R., 1995. Osady powierzchni dna (in Polish). In: Atlas geologiczny Południowego Bałtyku (ed. J.E. Mojski). Polish Geological Institute, Sopot-Warszawa.

Lørseth, T., 1999. Submarine Massflow Sedimentation. Springer, Berlin.

Lurton, X., 2002. An Introduction to Underwater Acoustics. Springer, Berlin.

Łęgowski, S., 1925. Zmiany w ukształtowaniu Półwyspu Helskiego (in Polish). Czasopismo Geograficzne, 3: 142-143.

Masson, D.G., Harbitz, C.B., Wynn, R.B., Pedersen, G., Lrvholt, F., 2006. Submarine landslides: processes, triggers and hazard prediction. Philosophical Transactions of the Royal Society, A, 364: 2009-2039.

McAdoo, B.G., Pratson, L.F., Orange, D.L., 2000. Submarine landslide geomorphology, US continental slope. Marine Geology, 169: 103-136.

Miętus, M., Jakusik, E., 2005. Charakterystyka wiatru i falowania w rejonie cypla Półwyspu Helskiego (in Polish). In: Stan zagro enia Półwyspu Helskiego (ed. J. Cyberski): 223-238. Gdańskie Towarzystwo Naukowe, Gdańsk.

Miętus, M., Filipiak, F., Owczarek, M., 2005. Zagro enia zjawiskami meteorologicznymi i klimatycznymi Półwyspu Helskiego (in Polish). In: Stan i zagro enia Półwyspu Helskiego (ed. J. Cyberski): 59-76. Gdańskie Towarzystwo Naukowe, Gdańsk.

Migoń, P., 2015. Geomorfologia (in Polish). PWN, Warszawa.

Mulder, T., Cochonat, P., 1996. Classification of offshore mass movements. Journal of Sedimentary Research, 66: 43-57.

Musielak, S., 1989. Remarks on the genesis of the Hela Peninsula in the light of new data (in Polish with English summary). Studia i Materiały Oceanograficzne, 56: 311-321.

Nemec, W., 1990. Aspects of sediment movement on steep delta slopes. In: Coarse-Grained Deltas (eds. A. Colella and D.B. Prior): 29-74. Blackwell Publishing Ltd., Oxford.

Pilarski, M., Wójcik, R., Biernacik, D., Filipiak, J., Jakusik, E., Marosz, M., Owczarek, M., Miętus, M., 2011. Warunki klimatyczne (in Polish). In: Stan środowiska polskiej strefy przybrze nej Bałtyku w latach 1986-2005 (eds. M. Sztobryn and M. Miętus): 19-56. IMGW, seria Monografie, Warszawa.

Pikies, R., Jurowska, Z., 1992. Mapa geologiczna dna Bałtyku 1:200 000, arkusz Puck (in Polish). Państwowy Instytut Geologiczny, Warszawa.

Prior, D.B., Suhayda, J.N., 1979. Application of infinite slope analysis to subaqueous sediment instability, Mississippi delta. Engineering Geology, 14: 1-10.

Przezdziecki, P., 2004. Seismostratigraphy of Quaternary sediments in the Polish part of the Baltic Sea (in Polish with English summary). Biuletyn Państwowego Instytutu Geologicznego, 413: $81-126$.

Rucińska-Zjadacz, M., 2013. Morfolitodynamika cypla Półwyspu Helskiego (in Polish). Ph.D thesis. University of Gdańsk, Gdynia.

Rucińska-Zjadacz, M., 2015. Budowa i stan zachodniej części Cypla Helskiego (in Polish). In: Procesy geologiczne w strefie brzegowej morza (ed. M. Witak): 32-42. University of Gdańsk, Gdańsk.
Rucińska-Zjadacz, M., Rudowski, S., 2008. Formy i procesy subakwalnego stoku bariery piaszczystej na przykładzie Cypla Helskiego (in Polish). Landform Analysis, 9: 212-213.

Rucińska-Zjadacz, M., Rudowski, S., 2009. Underwater slope relief of Cape Hel. Oceanological and Hydrobiological Studies, 38 (Supp. I): 111-119.

Rucińska-Zjadacz, M., Rudowski, S., 2015. Morpholithodynamic conditions of the tip of the Hel Peninsula, the Baltic Sea. Oceanological and Hydrobiological Studies, 44: 181-192.

Rudowski, S., Rucińska-Zjadacz, M., 2010. Badania dna morskiego metodami bezinwazyjnymi (in Polish). In: Fizyczne, biologiczne i chemiczne badania morskich osadów dennych (ed. J. Bolałek): 51-62. University of Gdańsk, Gdańsk.

Rudowski, S., Szefler, K., Nowak, J., Gajewski, Ł., Hac, B., 2009. Analiza profili sejsmoakustycznych $\mathrm{w}$ wyrobiskach $\mathrm{w}$ Zatoce Puckiej (in Polish). In: Program rekultywacji wyrobisk w zatoce Puckiej, Przyrodnicze podstawy i uwarunkowania (eds. L. Kruk-Dowgiałło and R. Opioła): 95-105. Maritime Institute in Gdańsk, Gdańsk.

Rudowski, S., Szefler, K., Zajfert, G., 2010. Gaz w osadach dna Zatoki Puckiej (in Polish). In: Geologia i Geomorfologia Pobrze a i południowego Bałtyku VIII (ed. W. Florek): 119-129. Akademia Pomorska w Słupsku, Słupsk.

Rudowski, S., Kałas, M., Gajewski, Ł., Hac, B., Nowak, J., Wnuk, K., Wróblewski, R., 2015. Badania podwodnego stoku Półwyspu Helskiego w rejonie portu Hel (in Polish). In: Procesy geologiczne w strefie brzegowej morza (ed. M. Witak): 19-31. University of Gdańsk, Gdańsk.

Rutkowski, J., Rudowski, S., Pietsch, K., Król, K., Krzysztofiak, L., 2003. Sediments of Lake Wigry (NE Poland) in the light of high-resolution seismics (seismoacoustic) survey. Limnological Review, 2: 363-371.

Sichi, G.O., Blondel, P., Gracia, E., 2005. Acoustic textures and seafloor characterization of submarine landslides - an example from the SW Iberian margin. In: Boundary Influances in High Frequency, Shallow Water Acoustics (eds. N.G. Pace and P. Blondel): 271-278. University of Bath, Bath.

Stanisławczyk, I., 2005. Zagro enia hydrologiczne Półwyspu Helskiego (in Polish). In: Stan i zagro enia Półwyspu Helskiego (ed. J. Cyberski): 251-259. Gdańskie Towarzystwo Naukowe, Gdańsk.

Stoker, M.S., Pheasant, J.B., Josenhans, H., 1997. Seismic methods and interpretation. In: Glaciated Continental Margins, an Atlas of Acoustic Images (eds. T.A. Davies, T. Bell, A.K. Cooper, H. Josenhans, L. Polyak, A. Solheim, M.S. Stoker and J.A. Stravers): 9-26. Springer, Berlin.

Tomczak, A., 1995a. Relief, geology and evolution of the Hel Spit, Polish Coast - past, present and future. Journal of Coastal Research, Special Issue, 22: 181-185.

Tomczak, A., 1995b. Budowa geologiczna strefy brzegowej. Półwysep Helski i Mierzeja Wiślana (in Polish). In: Atlas Geologiczny Południowego Bałtyku 1:500 000 (ed. J.E. Mojski): 48-51. Państwowy Instytut Geologiczny, Sopot-Warszawa.

Tomczak, A., 2005. Wybrane zagadnienia z przeszłości geologiczne i przyszłości Półwyspu Helskiego (in Polish). In: Stan i zagro enie Półwyspu Helskiego (ed. J. Cyberski): 13-58. GTN, Gdańsk.

Uścinowicz, S., 2003. Relative sea level changes, glacio-isostatic rebound and shoreline displacement in the Southern Baltic. Polish Geological Institute Special Papers, 10: 1-79.

Uścinowicz, S., 2014. Continental Shelf of the Baltic Sea. Geological Society Memoir, 41: 69-90.

Uścinowicz, S., Zachowicz, J., 1992. Mapa geologiczna dna Bałtyku 1:200 000, arkusz Gdańsk (in Polish). Państwowy Instytut Geologiczny, Warszawa.

Wicher, W., Necel, A., 2000. Seismostratigraphy of the nearshore sediments at Kępa Redłowska, Gulf of Gdańsk. Oceanological Studies, 29: 93-100.

Wiejacz, P., 2006. Trzęsienia ziemi w Okręgu Kaliningradzkim, 21 września 2004 (in Polish). Przegląd Geofizyczny, 50: 77-90.

Wünsche, E.H., 1904. Studien auf der Halbinsel Hela. Dresden. 